\title{
THE LAWFULNESS OF THE SEGREGATION DECISIONS
}

\author{
GHARLES L, BLAGK, JR, $\oplus$
}

If the cases outlawing segregation ${ }^{1}$ were wrongly decided, then they ought to be overruled. One can go further: if dominant professional opinion ever forms and settles on the belief that they were wrongly decided, then they will be overruled, slowly or all at once, openly or silently. The insignificant error, however palpable, can stand, because the convenience of settlement outweighs the discomfort of error. But the hugely consequential error cannot stand and does not stand. ${ }^{2}$

There is pragmatic meaning then, there is call for action, in the suggestion that the segregation cases cannot be justified. ${ }^{3}$ In the long run, as a corollary, there is practical and not merely intellectual significance in the question whether these cases were rightly decided. I think they were rightly decided, by overwhelming weight of reason, and I intend here to say why I hold this belief.

My liminal difficulty is rhetorical-or, perhaps more accurately, one of fashion. Simplicity is out of fashion, and the basic scheme of reasoning on which these cases can be justified is awkwardly simple. First, the equal protection clause of the fourteenth amendment should be read as saying that the Negro race, as such, is not to be significantly disadvantaged by the laws of the states. Secondly, segregation is a massive intentional disadvantaging of the Negro race, as such, by state law. No subtlety at all. Yet I cannot disabuse myself of the idea that that is really all there is to the segregation cases. If both these propositions can be supported by the preponderance of argument, the cases were rightly decided. If they cannot be so supported, the cases are in perilous condition.

As a general thing, the first of these propositions has so far as I know never been controverted in a holding of the Supreme Court. I rest here on

$\Varangle$ Henry R. Luce Professor of Jurisprudence, Yale Law School.

1. Brown v. Board of Educ. (The School Segregation Cases), 347 U.S. 483 (1954); Bolling v. Sharpe, 347 U.S. 497 (1954); New Orleans' City Park Improvement Ass'n v. Detiege, 358 U.S. 54 (1959); Gayle v. Browder, 352 U.S. 903 (1956); Holmes v. Atlanta, 350 U.S. 879 (1955); Mayor \& City Council v. Dawson, 350 U.S. 877 (1955); Muir v. Louisville Park Theatrical Ass'n, 347 U.S. 971 (1954).

2. Cf. Pollak, Racial Discrimination and Judicial Integrity: A Reply to Professor Wechsler, 108 U. PA. L. REv. 1, 31 (1959). I am indebted throughout to this Article, though the rationale $I$ offer in support of the decisions differs irom Professor Pollak"s. His, however, seems to me a sound alternative ground for the desegregation holdings.

3. See Wechsler, Tow'ard Neutral Principles of Constitutional Law, 73 Hanv. L. Rev. 1, 34 (1959). The present Article was immediately suggested by Proiessor Wechsler's questionings. It is not, however, to be looked on as formal "reply," since I cover here only one part of the ground he goes over, and since my lines of thought are only partly responsive in terms to the questions as he sees them. 
the solid sense of The Slanghterhouse Cases ${ }^{4}$ and of Strauder v. West Virginia, ${ }^{5}$ where Mr. Justice Strong said of the fourteenth amendment:

It ordains that no State shall make or enforce any laws which shall abridge the privileges or immunities of citizens of the United States (evidently referring to the newly made citizens, who, being citizens of the United States, are declared to be also citizens of the State in which they reside). It ordains that no State shall deprive any person of life, liberty, or property, without due process of law, or deny to any person within its jurisdiction the equal protection of the laws. What is this but declaring that the law in the States shall be the same for the black as for the white; that all persons, whether colored or white, shall stand equal before the laws of the States, and, in regard to the colored race, for whose protection the amendment was primarily designed, that no discrimination shall be made against them by law because of their color? The words of the amendment, it is true, are prohibitory, but they contain a necessary implication of a positive immunity, or right, most valuable to the colored race,-the right to exemption from unfriendly legislation against them distinctively as colored,-exemption from legal discriminations, implying inferiority in civil society, lessening the secturity of their enjoyment of the rights which others enjoy, and discriminations which are steps towards reducing them to the condition of a subject race. ${ }^{6}$

If Plessy $v$. Ferguson ${ }^{\top}$ be thought a faltering from this principle, I step back to the principle itself. But the Plessy Court clearly conceived it to be its task to show that segregation did not really disadvantage the Negro, except through his own choice. 8 There is in this no denial of the Slaughterhousc and Strauder principle; the fault of Plessy is in the psychology and sociology of its minor premise.

The lurking difficulty lies not in "racial" cases but in the total philosophy of "equal protection" in the wide sense. "Equal protection," as it applies to the whole of state law, must be consistent with the imposition of disadvantage on some, for all law imposes disadvantage on some; to give driver's licences only to good drivers is to disadvantage bad drivers. Thus the word "reasonable" necessarily finds its way into "equal protection," in the application of the latter concept to law in general. And it is inevitable, and right, that "reasonable," in this broader context, should be given its older sense of "supportable by reasoned considerations." "Equal" thereby comes to mean not really "equal," but "equal unless a fairly tenable reason exists for inequality."

4. 83 U.S. (16 Wall.) 36 (1873).

5. 100 U.S. $303(1880)$.

6. Id. at 307-08.

7. 163 U.S. 537 (1896).

8. "We consider the underlying fallacy of the plaintiff's argument to consist in the assumption that the enforced separation of the two races stamps the colored race with a badge of inferiority. If this be so, it is not by reason of anything found in the act, but solely because the colored race chooses to put that construction upon it." Id. at 551. (Emphasis added.) The curves of callousness and stupidity intersect at their respective maxima.

9. See Lindsley v. Natural Carbonic Gas Co., 220 U.S. 61 (1911). 
But the whole tragic background of the fourteenth amendment forbids the feedback infection of its central purpose with the necessary qualifications that have attached themselves to its broader and so largely accidental radiations. It may have been intended that "equal protection" go forth into wider fields than the racial. But history puts it entirely out of doubt that the chief and all-dominating purpose was to ensure equal protection for the Negro. And this intent can hardly be given the self-defeating qualification that necessity has written on equal protection as applied to carbonic gas. If it is, then "equal protection" for the Negro means "equality until a tenable reason for inequality is proferred." On this view, Negroes may hold property, sign wills, marry, testify in court, walk the streets, go to (even segregated) school, ride public transportation, and so on, only in the event that no reason, not clearly untenable, can be assigned by a state legislature for their not being permitted to do these things. That cannot have been what all the noise was about in 1860 .

What the fourteenth amendment, in its historical setting, must be read to say is that the Negro is to enjoy equal protection of the laws, and that the fact of his being a Negro is not to be taken to be a good enough reason for denying him this equality, however "reasonable" that might seem to some people. All possible arguments, however convincing, for discriminating against the Negro, were finally rejected by the fourteenth amendment.

It is sometimes urged that a special qualification was written on the concept of "equality" by the history of the adoption of the amendment-that an intent can be made out to exclude segregation from those legal discriminations invalidated by the requirement of equality, whether or not it actually works inequality. This point has been discussed and documented by Professor Alexander Bickel, ${ }^{10}$ who, though he finds convincing arguments for the conclusion that school segregation was not among the evils the framers of the amendment intended for immediate correction, ${ }^{11}$ suggests that they intended at the same time to set up a general concept for later concrete application. ${ }^{12}$ Other recent writers take somewhat similar views. ${ }^{13}$ The data brought forward by Professor Bickel do not seem to me as persuasive, on his first point, as they do to him.t4

10. Bickel, The Original Understanding and the Segregation Decision, 69 Hanv. L. REv. 1 (1955).

11. Id. at 58.

12. Id. at $61-65$.

13. Wechsler, supra note 3, at 31-32; Pollak, supra note 2 , at 25.

14. Actually, the question of my dissent from Professor Bictel's conclusions depends on their exact meaning. In his data I find, to be sure, a case for concluding that the relevant people did not "intend" to abolish segregation, in the sense that they had nu positive and consciously formed intention of doing so. That conclusion means little when one is dealing with general language. I am not convinced that a sufficient equivalency is made out between the Civil Rights Bill and the fourteenth amendment (there being no relevant legislative history whatever on the amendment as such) to justify attaching the bill's history to the amendment for the purpose of establishing a definitely formed intent to exclude segregation from the prohibitive ambit of the amendment's general words-a totally different meaning of the predicate "did not intend." The motive for insertion of 
But in supporting his second point he develops a line of thought tending to establish that the legislative history does not render the segregation decisions improper, and I am glad to join him in that practical conclusion. I would add only one point: The question of the "intent" of the men of 1866 on segregation as we know it calls for a far chancier guess than is commonly supposed, for they were unacquainted with the institution as it prevails in the American South today. To guess their verdict upon the institution as it functions in the midtwentieth century supposes an imaginary hypothesis which grows more preposterous as it is sought to be made more vivid. They can in the nature of the case have bequeathed us only their generalities; the specifics lay unborn as they disbanded. I do not understand Professor Bickel to hold a crucially different view.

Then does segregation offend against equality? Equality, like all general concepts, has marginal areas where philosophic difficulties are encountered. But if a whole race of people finds itself confined within a system which is set up and continued for the very purpose of keeping it in an inferior station, and if the question is then solemnly propounded whether such a race is being treated "equally," I think we ought to exercise one of the sovereign prerogatives of philosophers-that of laughter. The only question remaining (after we get our laughter under control) is whether the segregation system answers to this description.

Here I must confess to a tendency to start laughing all over again. I was raised in the South, in a Texas city where the pattern of segregation was firmly fixed. I am sure it never occurred to anyone, white or colored, to question its meaning. The fiction of "equality" is just about on a level with the fiction of "finding" in the action of trover. I think few candid southerners deny this. Northern people may be misled by the entirely sincere protestations of many southerners that segregation is "better" for the Negroes, is not intended to hurt them. But I think a little probing would demonstrate that what is meant is that it is better for the Negroes to accept a position of inferiority, at least for the indefinite future.

But the subjectively obvious, if queried, must be backed up by more public materials. What public materials assure me that my reading of the social meaning of segregation is not a mere idiosyncracy?

First, of course, is history. Segregation in the South comes down in apostolic succession from slavery and the Dred Scott case. The South fought to keep slavery, and lost. Then it tried the Black Codes, and lost. Then it looked around for something else and found segregation. The movement for segregation was an integral part of the movement to maintain and further

the present equal protection clause seems to me, on Professor Bickel's evidence, simply mysterious. Cf. Fairman, Does the Fourteenth Amendment Incorporate the Bill of Rights?, 2 StaN. L. Rev. 5, 41 (1949). Obviously, the development, qualification, and support of these points would call for more discussion than is warrantable in the present context, given the practical agreement in which Professor Bickel and I (as I belicve) find ourselves. 
"white supremacy"; its triumph (as Professor Woodward has shown) represented a triumph of extreme racialist over moderate sentiment about the Negro. ${ }^{15}$ It is now defended very largely on the ground that the Negro as such is not fit to associate with the white.

History, too, tells us that segregation was imposed on one race by the other race; consent was not invited or required. Segregation in the South grew up and is kept going because and only because the white race has wanted it that way-an incontrovertible fact which in itself hardly consorts with equality. This fact perhaps more than any other confirms the picture which a casual or deep observer is likely to form of the life of a southern community-a picture not of mutual separation of whites and Negroes, but of one in-group enjoying full normal communal life and one out-group that is barred from this life and forced into an inferior life of its own. When a white southern writer refers to the woes of "the South," do you not know, does not context commonly make it clear, that he means "white southerners" ? When you are in Leeville and hear someone say "Leeville High," you know he has reference to the white high school; the Negro school will be called something else-Carver High, perhaps, or Lincoln High to our shame. That is what you would expect when one race forces a segregated position on another, and that is what you get.

Segregation is historically and contemporaneously associated in a functioning complex with practices which are indisputably and grossly discriminatory. I have in mind especially the long-continued and still largely effective exclusion of Negroes from voting. Here we have two things. First, a certain group of people is "segregated." Secondly, at about the same time, the very same group of people, down to the last man and woman, is barred, or sought to be barred, from the common political life of the community-from all political power. Then we are solemnly told that segregation is not intended to harm the segregated race, or to stamp it with the mark of inferiority. How long must we keep a straight face?

Here it may be added that, generally speaking, segregation is the pattern of law in communities where the extralegal patterns of discrimination against Negroes are the tightest, where Negroes are subjected to the strictest codes of "unwritten law" as to job opportunities, social intercourse, patterns of housing, going to the back door, being called by the first name, saying "Sir," and all the rest of the whole sorry business. Of course these things, in themselves, need not and usually do not involve "state action," and hence the fuurteenth amendment cannot apply to them. But they can assist us in understanding the meaning and assessing the impact of state action.

"Separate but equal" facilities are almost never really equal. Sometimes this concerns small things-if the "white" men's room has mixing hot and cold taps, the "colored" men's room will likely have separate taps; it is

15. Woodward, The Strange Career of Jas Crow ch. II Capitulations to Rocism, at 49-95 (1957). See generally id. passim. 
always the back of the bus for the Negroes; "Lincoln Beach" will rarely if ever be as good as the regular beach. Sometimes it concerns the most vital matters-through the whole history of segregation, colored schools have been so disgracefully inferior to white schools that only ignorance can excuse those who have remained acquiescent members of a community that lived the Molochian child-destroying lie that put them forward as "equal."

Attention is usually focused on these inequalities as things in themselves, correctible by detailed decrees. I am more interested in their very clear character as evidence of what segregation means to the people who impose it and to the people who are subjected to it. This evidentiary character cannot be erased by one-step-ahead-of-the-marshal correction. Can a system which, in all that can be measured, has practiced the grossest inequality, actually have been "equal" in intent, in total social meaning and impact? "Thy speech maketh thee manifest ..."; segregation, in all visible things, speaks only haltingly any dialect but that of inequality.

Further arguments could be piled on top of one another, for we have here to do with the most conspicuous characteristic of a whole regional culture. It is actionable defamation in the South to call a white man a Negro. ${ }^{10} \mathrm{~A}$ small proportion of Negro "blood" puts one in the inferior race for segregation purposes $;^{17}$ this is the way in which one deals with a taint, such as a carcinogene in cranberries.

The various items I have mentioned differ in weight; not every one would suffice in itself to establish the character of segregation. Taken together they are of irrefragable strength. The society that has just lost the Negro as at slave, that has just lost out in an attempt to put him under quasi-servilc" "Codes," the society that views his blood as a contamination and his name" as an insult, the society that extralegally imposes on him every humiliating mark of low caste and that until yesterday kept him in line by lynching-this society, careless of his consent, moves by law, first to exclucle him from voting, and secondly to cut him off from mixing in the general public life of the community. The Court that refused to see inequality in this cutting off would be making the only kind of law that can be warranted outrageous in advance -law based on self-induced blindness, on flagrant contradiction of known fact.

I have stated all these points shortly because they are matters of common notoriety, matters not so much for judicial notice as for the background lnowledge of educated men who live in the world. A court may advise itself of them as it advises itself of the facts that we are a "religious people," that the country is more industrialized than in Jefferson's day, that children are the natural objects of fathers' bounty, that criminal sanctions are commonly thought to deter, that steel is a basic commodity in our economy, that the imputation of unchastity is harmful to a woman. Such judgments, made on

16. See Mangum, Legal Status of tee Negro ch. II Libel and Slander (1940), citing and discussing cases.

17. Id. ch. I. 
such a basis, are in the foundations of all law, decisional as well as statutory; it would be the most unneutral of principles, improvised ad hoc, to require that a court faced with the present problem refuse to note a plain fact aboul the society of the United States-the fact that the social meaning of segregation is the putting of the Negro in a position of walled-off inferiority-or the other equally plain fact that such treatment is hurtful to human beings. Southern courts, on the basis of just such a judgment, have held that the placing of a white person in a Negro railroad car is an actionable humiliation; ${ }^{18}$ must a court pretend not to know that the Negro's situation there is humiliating :

I think that some of the artificial mist of puzzlement called into being around this question originates in a single fundamental mistake. The issue is seen in terms of what might be called the metaphysics of sociology: "Mlust Segregation Amount to Discrimination?" That is an interesting question; someday" the methods of sociology may be adequate to answering it. But it is not our question. Our question is whether discrimination inheres in that segregation which is imposed by law in the twentieth century in certain specific states in the American Union. And that question has meaning and can find an answer only on the ground of history and of common knowledge about the facts of life in the times and places aforesaid.

Now I need not and do not maintain that the evidence is all one way; it never is on issues of burning, fighting concern. Let us not question here the good faith of those who assert that segregation represents no more than an attempt to furnish a wholesome opportunity for parallel development of the races; let us rejoice at the few scattered instances they can bring forward to support their view of the matter. But let us then ask which balance-pan flies upward. ${ }^{19}$

The case seems so onesided that it is hard to make out what is being protested against when it is asked, rhetorically, how the Court can possibly advise itself of the real character of the segregation system. It seems that what is being said is that, while no actual doubt exists as to what segregation is for and what kind of societal pattern it supports and implements, there is no ritually sanctioned way in which the Court, as a Court, can permissibly learn what is obvious to everybody else and to the Justices as individuals. But surely,

18. See id. at 209-10, 219-20.

19. Professor Wechsler, in the Article to which I am in several points respunding, says: "The virtue or demerit of a judgment turns ... entirely on the reasons that support it and their adequacy to maintain any choice of values it decrees, or, it is ritol to add, to maintain the rejection of a claim that any given choice should be decredd." Wechsler, supra note 3, at 19-20. (Emphasis added.) Unless it chose to rely without reexamination on the sociology of Plessy v. Ferguson, or to follow the evasive, futile, and novel procedure of leaving the matter to Congress (see id. at 31-32, rejecting both these nonsolutions, and on the latter point, see my forthcoming The People and the Court, at 13739), what kind of an opinion could the Court have written sustaining the affirmative thesis that segregation as we know it really is equal-especially in view of the fact, which I suppose would be conceded, that the very least one can possibly say is that no strong presumption of validity supports racially classificatory state laws? 
confronted with such a problem, legal acumen has only one proper task-that of developing ways to make it permissible for the Court to use what it knows; any other counsel is of despair. And, equally surely, the fact that the Court has assumed as true a matter of common knowledge in regard to broad societal patterns, is (to say the very least) pretty far down the list of things to protest against.

I conclude, then, that the Court had the soundest reasons for judging that segregation violates the fourteenth amendment. These reasons make up the simple syllogism with which I began: The fourteenth amendment commands equality, and segregation as we know it is inequality.

Let me take up a few peripheral points. It is true that the specifically hurtful character of segregation, as a net matter in the life of each segregated individual, may be hard to establish. ${ }^{20}$ It seems enough to say of this, as Professor Pollak has suggested, ${ }^{21}$ that no such demand is made as to other constitutional rights. To have a confession beaten out of one might in some particular case be the beginning of a new and better life. To be stubjected to a racially differentiated curfew might be the best thing in the world for some individual boy. A man might ten years later go back to thank the policeman who made him get off the platform and stop making a fool of himself. Religious persecution proverbially strengthens faith. We do not ordinarily go that far, or look so narrowly into the matter. That a practice, on massive historicil evidence and in common sense, has the designed and generally apprehended effect of putting its victims at a disadvantage, is enough for law. At least it always has been enough.

I can heartily concur in the judgment that segregation harms the white as much as it does the Negro. ${ }^{22}$ Sadism rots the policeman; the suppressor of thought loses light; the community that forms into a mob, and goes down and dominates a trial, may wound itself beyond healing. Can this reciprocity of hurt, this fated mutuality that inheres in all inflicted wrong, serve to validate the wrong itself?

Finally it is doubtless true that the School Segregation Cases, and perhaps others of the cases on segregation, represented a choice between two kinds of freedom of association. Freedom from the massive wrong of segregation entails a corresponding loss of freedom on the part of the whites who must now associate with Negroes on public occasions, as we all must on such occasions associate with many persons we had rather not associate with. It is possible to state the competing claims in symmetry, and to ask whether there are constitutional reasons for preferring the Negroes' desire for merged participation in public life to the white man's desire to live a public life without Negroes in proximity. ${ }^{23}$

\footnotetext{
20. See Wechsler, supra note 3 , at 32-33.

21. Pollak, supra note 2 , at 28 .

22. See Wechsler, supra note 3 , at 34 .

23. Ibid.
} 
The question must be answered, but I would approach it in a way which seems to me more normal-the way in which we more usually approach comparable symmetries that might be stated as to all other asserted rights. The fourteenth amendment forbids inequality, forbids the disadvantaging of the Negro race by law. It was surely anticipated that the following of this directive would entail some disagreeableness for some white southerners. The disagreeableness might take many forms; the white man, for example, might dislike having a Negro neighbor in the exercise of the latter's equal right to own a home, or dislike serving on a jury with a Negro, or dislike having Negroes on the streets with him after ten o'clock. ${ }^{24}$ When the directive of equality cannot be followed without displeasing the white, then something that can be called a "freedom" of the white must be impaired. If the fourteenth amendment commands equality, and if segregation violates equality, then the status of the reciprocal "freedom" is automatically settled.

I find reinforcement here, at least as a matter of spirit, in the fourteenth amendment command that Negroes shall be "citizens" of their States. It is hard for me to imagine in what operative sense a man could be a "citizen" without his fellow citizens' once in a while having to associate with him. If, for example, his "citizenship" results in his election to the School Board, the white members may (as recently in Houston) put him off to one side of the room, but there is still some impairment of their freedom "not to associate." That freedom, in fact, exists only at home; in public, we have to associate with anybody who has a right to be there. The question of our right not to associate with him is concluded when we decide whether he has a right to be there.

I am not really apologetic for the simplicity of my ideas on the segregation cases. The decisions call for mighty diastrophic change. We ought to call for such change only in the name of a solid reasoned simplicity that takes law out of artfulness into art. Only such grounds can support the nation in its resolve to uphold the law declared by its Court; only such grounds can reconcile the white South to what must be. Elegantia juris and conceptual algebra have here no place. Without pretending either to completeness or to definitiveness of statement, I have tried here to show reasons for believing that we as lawyers can without fake or apology present to the lay community, and to ourselves, a rationale of the segregation decisions that rises to the height of the great argument.

These judgments, like all judgments, must rest on the rightness of their law and the truth of their fact. Their law is right if the equal protection clause in the fourteenth amendment is to be taken as stating, without arbitrary exceptions, a broad principle of practical equality for the Negro race, inconsistent with any device that in fact relegates the Negro race to a position of

24. The white inhabitants of Mobile in their corporate capacity moved to protcet this particular "freedom not to associate" in 1909. See WoopWAsp, op. cit. sipra note 14, at $86-87$. 
inferiority. Their facts are true if it is true that the segregation system is actually conceived and does actually function as a means of keeping the Negro in a status of inferiority. I dare say at this time that in the end the decisions will be accepted by the profession on just that basis. Opinions composed under painful stresses may leave much to be desired $;^{25}$ it may be that the per curiam device has been unwisely used. But the judgments, in law and in fact, are as right and true as any that ever was uttered.

25. I do not mean here to join the hue and cry against the Brozem opinion. The charge that it is "sociological" is either a truism or a canard-a truism if it mcans that the Court, precisely like the Plessy Court, and like innumerable other courts facing innumerable other issues of law, had to resolve and did resolve a question about social fact; a canard if it means that anything like principal reliance was placed on the formally "scientific" authorities, which are relegated to a footnote and treated as mercly corroboratory of common sense. It seems to me that the venial fault of the opinion consists in its not spelling out that segregation, for reasons of the kind $I$ have brought forward in this Article, is perceptibly a means of ghettoizing the imputedly inferior race. (I would conjecture that the motive for this omission was reluctance to go into the distasteful details of the southern caste system.) That such treatment is gencrally not good for children needs less talk than the Court gives it. 


\title{
THE YALE LAW JOURNAL
}

\author{
Alan Appelibauar \\ Editor-in-Chief \\ Janies MCC. Jonustone \\ Gitbert Paul Verait \\ Article \& Bool. \\ Review Editors \\ Eugene I. Lasmest \\ Managing \& Case \\ Editor
}

James M. EDwards

STEPHEN MANN

Donaid G. Marshail

ROBERT I. WEINBERG

Note \& Comment Editors
Matthew T. Adaris

David Albenda.

NeAIE M. AlberT

Hersher YeLLEN ALLerHand

Hurd Baruch

ARTHUR J. BERK

George B. Driesen

EIIEzer EreLI

David R. EVANS

Stuart B. Goldatan
Lawrence G. G oodaran

Willtaxs S. Greenawalt

Richard S. Harrison

BenjantrN T. Hoperns, II

Robert E. Hudec

ROBERT A. JOHNSON

ARON Katz.

ZANE KIEIN

N. Hersched Koblenz

Bruce MIONTGOATERY

SAASUEL MFYeRS
Míchael J. Nassau

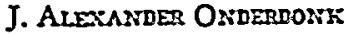

Alan D. Pefielser

Herbert Schrember

Ruchard Lauder Sutto:

Herbert S. WANdzR

Donalo P. Wefen

Patricia W. Wermoerg

SIDNEY MF. WOLINSKF:

Jere A. Younic

MiARIE MCDÍagoN

Business Secretary

\section{CONTRIBUTORS TO THIS ISSUE}

JoHN RED. B.S.S. 1952, Georgetown University; LL.B. 1955, Harvard University; M.A. 1957, University of New Hampshire. Mfember of the New Hampshire Bar. Current1y studying on a Ford Foundation grant at New York University Law School.

Charles I. Black, Jr. B.A. 1935, MI.A. 1938, University of Texas; LL.B. 1943, Yale University. Member of the New York Bar. Henry R. Luce Professor of Jurisprudence, Yale Law School. 